\title{
A Baseline Study on Groundwater Quality of the Tourist Island, Pulau Tiga, Sabah, Malaysia
}

\author{
Chin Yik Lin (Corresponding Author) \\ School of Science and Technology, Universiti Malaysia Sabah \\ Beg Berkunci 2073, 88999, Kota Kinabalu, Sabah, Malaysia \\ Tel: 60-88-325-808 E-mail: cy_lin_ars@hotmail.com \\ Mohd Harun Abdullah \\ School of Science and Technology, Universiti Malaysia Sabah \\ Beg Berkunci 2073, 88999, Kota Kinabalu, Sabah, Malaysia \\ Tel: 60-88-325-808 E-mail: harunabd@ums.edu.my \\ Ahmad Zaharin Aris \\ Faculty of Environmental Studies, Universiti Putra Malaysia \\ 43400 UPM, Serdang, Selangor, Malaysia \\ Tel: 60-88-325-808 E-mail: zaharin@env.upm.edu.my \\ Sarva Mangala Praveena \\ School of Science and Technology, Universiti Malaysia Sabah \\ Beg Berkunci 2073, 88999, Kota Kinabalu, Sabah, Malaysia \\ Tel: 60-88-325-808Ｅ-mail: smpraveena@gmail.com
}

This research was financially supported by the Ministry of Higher Eduction, Malaysia through the Fundamental Research Grant No. FRG0050-ST-1/2006. Permission from the Sabah Park Trustees for the study site is highly acknowledged. Besides, the authors would also opt to acknowledge Chua Li Ying, Lim Kuan Leang and Ooi Chun Wei for their assistance during the fieldworks.

\begin{abstract}
Pulau Tiga is a group of small islands located at Kimanis Bay off the western coast of Sabah. This preliminary study on groundwater of Pulau Tiga is undertaken to provide guidance and baseline data for future references. An understanding of the chemistry and behavior of water in the island aquifer is crucial for the determination of the availability of freshwater, and also to create a platform for considering proper management and successful remediation of groundwater resources on island to prevent over exploitation of such limited resources. Groundwater samples were collected from five wells on Pulau Tiga to understand the groundwater chemistry based on various ion composition $\left(\mathrm{Ca}^{2+}, \mathrm{Mg}^{2+}, \mathrm{Na}^{+}\right.$, $\mathrm{K}^{+}, \mathrm{HCO}_{3}^{-}, \mathrm{SO}_{4}{ }^{2-}, \mathrm{Cl}^{-}, \mathrm{NO}_{3}{ }^{-}$), in situ parameters such as DO (Dissolved oxygen), EC (Electrical conductivity), TDS (Total dissolved solids), $\mathrm{pH}$, salinity and temperature. Even though groundwater in Pulau Tiga was constantly subject to abstraction activities for its tourism purposes, preliminary results showed that the groundwater still remains freshwater type. The Piper diagram suggested that the groundwater facies generally range from $\mathrm{Ca}-\mathrm{HCO}_{3}$ to $\mathrm{Ca}-\mathrm{Cl}$ waters type. The processes influencing the groundwater chemistry are mainly dissolution of minerals.
\end{abstract}

Keywords: Groundwater, Pulau Tiga, Hydrochemical, Hydrochemical Facies, Groundwater Chemistry 


\section{Introduction}

Pulau Tiga is a group of small uninhabited Malaysian islands in Kimanis Bay off the western coast of Sabah. Pulau Tiga is located between $5^{\circ} 42^{\prime}$ and $5^{\circ} 43^{\prime}$ and $115^{\circ} 37^{\prime}$ and $115^{\circ} 39^{\prime}$, South West from Kota Kinabalu with a distance of 55 $\mathrm{km}$ and $12 \mathrm{~km}$ North East from Klias peninsular (Sanudin et al., 1999). Which covers approximately 725 hectares with length of approximately $5.2 \mathrm{~km}$ and width of $1.8 \mathrm{~km}$. Pulau Tiga is the biggest island among those three islands. Land use is typically residential or undeveloped. Pulau Kalampunian Besar and Pulau Kalampunian Kecil are located at $1 \mathrm{~km}$ North from Pulau Tiga, respectively. At present, approximately thousands of people visit Pulau Tiga every year. Groundwater is the only source for regular water supply in the island. With the growing number of tourists and human activities on the island, the demand for groundwater in this island has increased apparently. Since its existence has become the most important source for the small island's community, pumping from the upper phreatic zone is widely practiced on the island which may lead to deterioration of groundwater quality. Furthermore, there is lack of studies done in this island to understand the change of groundwater chemistry in such condition. Thus, this preliminary research was set up to study the groundwater quality on the island.

\subsection{Site Description}

Pulau Tiga has unique hydrometeorological characteristics with wide variation in the rainfall pattern (average 2816.4 $\mathrm{mm}$ ). The mean temperature is approximately $23{ }^{\circ} \mathrm{C}-32{ }^{\circ} \mathrm{C}$. Most of its water comes from precipitation. The island received heavy precipitation during the southwest monsoon (April - October) and the southeast monsoon (October February) prevail. This high volume of rainfall is mainly depends with transition of monsoon seasons. However, some rains also occur during the month of March. The annual average rainfall distribution from 1995 to 2007 is shown in Figure 2. While, the monthly average rainfall for year 2007 recorded at Kuala Penyu is shown in Figure 3, respectively. The recharge of aquifer comes from direct infiltration of rainwater and lateral inflow from the hills. On the contrary, the discharge of the aquifer is a result of pumping activities, outflow to the sea (subterranean or direct), and drainage to the swampy land. During the wet season there is one tidal channel that allows the mixing of seawater into the brackish mangrove swamp water on this island. The geology of Pulau Tiga is unique in view of the presence of mud volcano activity. The most active mud volcano activity is located at the highest point of Puncak Mat Salleh. Geologically, the study area is part of Quaternary sedimentary terrain. Based on the coastal structure analysis, Pulau Tiga is located at the junction of two widely spread formation in this region, namely the Crocker and Belait formations. The island consists of two distinct lithological units. According to Sanudin et al., (1999) the uppermost formation is Belait underlain by Quaternary thick mud volcanic sequences. The presence of Setap Shale formation on the island is well-known for its actively petroleum production. Quaternary sedimentary formation of Pulau Tiga unconformably overlay Neogen. Pulau Tiga is constituted by material of sedimentary origin that forms a chaotic accumulation of fluvial and volcanic materials located at the vent of mud volcano. Therefore, the island is mostly covered with mud volcanic soil. This mud volcanic soil is covered with mud and shale. Although there are a great variety of rock types within the study area, the vast majority is made up of Crocker, Setap Shale and Belait rock fragments. These rock fragments being ejected out together with mud volcano during the mud volcano eruption events. In general, these kinds of bedrocks are known as clastic sedimentary aquifer. Clastic sedimentary rocks consist of mudstone (e.g. shale), sandstone and conglomerate. Mudstone and sandstone are by far the most common of these, and sandstone is the most common aquifer type because it is normally more permeable than mudstone. There are trace amount of carbonates rock found in Pulau Tiga. Few outcrops of carbonate rocks can be found within the stratigraphy of the study area. Presence of carbonate terraces are sighted within the cliff of Pulau Tiga. However, the presence of these rocks is discontinuous. Therefore, it is believe that the carbonate rocks are just single block fragments. Microscopy study indicates there are various kinds of foram's exoskeleton, algae and coral cemented by carbonate or calcite as matrix in carbonate rocks. Besides, there is presence of aragonite as trace minerals. Few kinds of micro fossils such as foraminifer plankton and corals had been found embedded in the carbonate terraces. The foraminifer species from the carbonate terraces found in the coastal plain of Pulau Tiga aged from mid Miocene (Sanudin et al., 1999). In this paper, the authors have opted to examine the groundwater quality, major dissolved cation and anion constituents in the groundwater of Pulau Tiga and as well as to classify the types of groundwater chemistry in the island aquifer.

\section{Material and Methods}

A total of 30 samples of groundwater in the study area were collected from 5 wells located on Pulau Tiga, respectively. The first sampling was conducted in August 2007 (dry period), and the second in November 2007 (wet period). The sampling wells are located at the low elevation area of the island. Currently, there are only 3 production wells (PT 1, PT 2 and PT 4) that are still constantly provide freshwater supply to the inhabitants on that island. The other two wells (PT 3 and PT 5) were temporary abandoned due to high salinity. Polyethylene bottles that soaked with $10 \% \mathrm{HNO}_{3}$ acid wash and pre-rinsed with distilled water were used to store groundwater samples based on the methods described in APHA (1995). Groundwater samples were collected by using Wildco Water Sampler. Triplicate samples were used to verify the sampling protocol (Allen et al., 2001). The precise locations of the sampling points were determined in the 
field through the development of the GARMIN 12 Channel Instrument, based on the principles of Global Positioning System (GPS). The exact longitude and latitude of the sampling points, hydrogeological data and well's features were summarised in Table 1. Through this study, graphical analyses were used to display the areal distribution of dissolved constituents throughout the Pulau Tiga aquifer. Statistical techniques were applied to analyse the groundwater quality data. Besides, the statistical analyses also provide us a clear view of the general chemical character of the groundwater of Pulau Tiga. Statistical analysis was undertaken by using correlation matrix. This analysis was undertaken by using the computer software SPSS 15 in order to verify and describe the relationships between the various determinants.

\subsection{Physico-chemical parameters}

In situ parameters such as temperature, electrical conductivity (EC), total dissolved solids (TDS), $\mathrm{pH}$, dissolved oxygen (DO), salinity and redox potential $(\mathrm{mV})$ were measured using probe Eutech EcoScan, Oakton Cond., EC-TDS Scan, YSI 650 and Eutech Salttester. Groundwater were analysed immediately following sample collection in order to acquire representatives values of ambient aquifer conditions. The samples were stored at $1-4{ }^{\circ} \mathrm{C}$ temperature prior to analysis in the laboratory. Water samples collected were filtered through a $0.45 \mu \mathrm{m}$ membrane filter paper (Millipore) using glass filtration unit and acidified with concentrated nitric acid $\left(\mathrm{HNO}_{3}\right)$ to lower the $\mathrm{pH}$ of samples $<2$ in order to prevent the adsorption occurred upon the container surface and precipitation of cations. Cation and anion such as chloride $\left(\mathrm{Cl}^{-}\right)$, bicarbonate $\left(\mathrm{HCO}_{3}^{-}\right)$, calcium $\left(\mathrm{Ca}^{2+}\right)$, magnesium $\left(\mathrm{Mg}^{2+}\right)$, sodium $\left(\mathrm{Na}^{+}\right)$and potassium $\left(\mathrm{K}^{+}\right)$were analysed in the Water Quality Laboratory of the School of Science and Technology, Universiti Malaysia Sabah, Malaysia. The major cations $\left(\mathrm{Na}^{+}, \mathrm{K}^{+}, \mathrm{Mg}^{2+}\right.$ and $\mathrm{Ca}^{2+}$ ) were determined using atomic absorption spectrophotometer (AAS Perkin Elmer - 4100). Sulfate $\left(\mathrm{SO}_{4}{ }^{2-}\right)$ and nitrate $\left(\mathrm{NO}_{3}{ }^{-}\right)$were detected using $\mathrm{HACH}(\mathrm{DR} / 2040)$ meter. $\mathrm{Cl}^{-}$and $\mathrm{HCO}_{3}{ }^{-}$were analysed using argentometric $\left(\mathrm{AgNO}_{3}\right)$ and titration methods $(\mathrm{HCl} 0.1 \mathrm{~N})$ as suggested by APHA (1995), respectively.

\section{Results and Discussion}

\subsection{In-situ parameters}

In-situ results for both sampling periods (August 2007 and November 2007) from triplicate samples were averaged into one number for inclusion in Table 2. The major cation $(\mathrm{Ca}, \mathrm{Mg}, \mathrm{Na}, \mathrm{K})$, major anion $\left(\mathrm{Cl}, \mathrm{HCO}_{3}{ }^{-}, \mathrm{SO}_{4}{ }^{2-}, \mathrm{NO}_{3}{ }^{-}\right)$of the groundwater and WHO (2004) guidelines for drinking water are shown in Table 4. The $\mathrm{pH}$ values of groundwater were between 6.84 to 7.33 and a median value of 7.02 for both sampling periods (August 2007 and November 2007). A look on the values (Table 2) reveals that all the samples had $\mathrm{pH}$ value within the permissible range of $6.5-8.5$ (WHO, 2004), no distinct groupings of these values were observed. The groundwater temperature is generally between $26.7^{\circ} \mathrm{C}$ to 29.9 ${ }^{\circ} \mathrm{C}$ and with an average value at $28.3^{\circ} \mathrm{C}$, which correspond with mean annual temperature.

Groundwater in Pulau Tiga has low mineralisation, as shown by the electrical conductivity (EC) measurements. EC of these groundwater sources varies from $861 \mu \mathrm{Scm}^{-1}$ to $1005 \mu \mathrm{Scm}^{-1}$ (August 2007) and $329 \mu \mathrm{Scm}^{-1}$ to $828 \mu \mathrm{Scm}^{-1}$ (November 2007). The EC decrease from $1005 \mu \mathrm{Scm}-1$ to $828 \mu \mathrm{Scm}-1$ is probably due to the dilution of groundwater by heavy precipitation (Mondal et al, 2007). Table 2 indicates that all the groundwater samples are below the WHO (2004) guideline of $1400 \mu \mathrm{S} / \mathrm{cm}$.

Total dissolve solids (TDS) varies from $164 \mathrm{mgl}^{-1}$ to $502 \mathrm{mgl}^{-1}$ in August 2007 and November 2007, respectively. The lowest value was recorded at station PT $5(165 \mathrm{mg} / \mathrm{L})$ in November 2007. The result indicates that the groundwater belongs to fresh water type and presently not under the influence of seawater intrusion (Mondal et al., 2007). Since there is absence of river and stream in Pulau Tiga, therefore, the groundwater recharge in Pulau Tiga is depends mainly on precipitation. As a general observation, lower TDS values were observed in November 2007 while higher TDS values were observed in August 2007, indicating the possibility of dilution effect of dry and wet period.

Low dissolved oxygen (DO) concentrations were recorded ranging between $1.08 \mathrm{mgl}^{-1}$ to $2.06 \mathrm{mgl}^{-1}$ on August 2007 . There was a slight increased in concentration of DO during dry period (November 2007) which ranging from $4.20 \mathrm{mgl}^{-1}$ to $6.12 \mathrm{mgl}^{-1}$. The salinity of groundwater varies between $0.1 \mathrm{ppt}$ to $0.5 \mathrm{ppt}$. Due to proximity with a tidal swamp channel, it was noted that groundwater samples in station PT 3 showed a comparatively higher salinity with other sampling locations during the sampling campaign in August. This can be explained by during dry season, which rainfall is relatively low, the saline water finds its way through tidal channels and it admixes with shallow coast aquifers. Hence, the salinity of groundwater in PT 3 becomes much higher in August.

\subsection{Laboratory Chemical Analysis}

\subsubsection{Anion constituents}

Groundwater sample for both sampling periods suggested $\mathrm{HCO}_{3}^{-}$ion concentration varies between $120 \mathrm{mgl}^{-1}$ to 330 $\mathrm{mgl}^{-1}$. The results apparently show that $\mathrm{HCO}_{3}{ }^{-}$is the dominant anion in the groundwater. Generally, dissolution of carbonate minerals by fresh water is the main source of calcium, magnesium and bicarbonates (Allen \& Matsuo, 2002). Hence, high concentration of $\mathrm{HCO}_{3}^{-}$may be explain by the dissolution of carbonate minerals which presence in the aquifer. Limestone and sandstone may also contribute to the presence of dissolved $\mathrm{HCO}_{3}^{-}$and $\mathrm{Ca}^{2+}$ (Chadha, 1999). In 
freshly recharged groundwater, $\mathrm{HCO}_{3}{ }^{-}$is typically the dominant anion (Aris et al., 2008). On the contrary, the comparatively low $\mathrm{HCO}_{3}{ }^{-}$concentration in station PT 3 and PT 5 may be explained by the occurrence of biological breakdown of organic carbon in the soil and the aquifer (Appelo \& Postma, 1993; Drever, 1997).

Sulfate contents in all sampling stations are said to be at normal level, with its concentration range between $25 \mathrm{mgl}^{-1}$ and $82 \mathrm{mgl}^{-1}$ for both sampling periods. Sulfate concentration in the area is generally low and therefore poses no problem to the groundwater quality. These low values are most probably due to the removal of $\mathrm{SO}_{4}{ }^{2-}$ by the action of bacteria (Amadi et al., 1989). From the correlation coefficient matrix for August 2007, a high positive correlation was found between electrical conductivity, sulfate and potassium contents, suggesting the large contribution of these elements to the groundwater chemical load. Nevertheless, occulted by sulfate and potassium the groundwater in Pulau Tiga is highly bicarbonate as a result of the presence of carbonate compounds in the reservoirs matrix (Fernandes et al., 2005). Figure 4 shows the dissolved $\mathrm{SO}_{4}{ }^{2-}$ are well correlated with $\mathrm{Cl}^{-}$concentration for both sampling period in August and November 2007 ( $r=0.776$, and $r=0.717$, respectively).

In this study, chloride $\left(\mathrm{Cl}^{-}\right)$concentrations obtained were in the range of $98.97 \mathrm{mgl}^{-1}$ to $287.84 \mathrm{mgl}^{-1}$ with an average value of $160.10 \mathrm{mgl}^{-1}$. Chemical analysis results indicate that $20 \%$ of the samples $(\mathrm{n}=30)$ had concentrations of chloride above $250 \mathrm{mgl}^{-1}$ that what is recommended by WHO (2004) as the maximum permissible limit for drinking water. PT 3 recorded a Cl${ }^{-}$concentration of $266.95 \mathrm{mgl}^{-1}$ in August and $241.42 \mathrm{mgl}^{-1}$ in November 2007, respectively, which shows the highest chloride concentration among all sampling stations. High chloride concentration may be due to the proximity of the well to a tidal channel and the poor muddy sediments present in the aquifer system which further infers saline intrusion. According to Cidu et al., (2006) $\mathrm{Cl}^{-}$may also derive from the interaction of water with marine-derived sediment. All these factors might be responsible for the relatively high $\mathrm{Cl}^{-}$concentration $\left(>50 \mathrm{mgl}^{-1}\right)$ in the groundwater of the area. Analyses of all groundwater samples in Pulau Tiga shows a decrease in chloride concentration with an average from $162.06 \mathrm{mgl}^{-1}$ (dry period) to $99.24 \mathrm{mgl}^{-1}$ (wet period). This suggests the possibility of hydrochemical processes such as seawater intrusion and that dilution with fresh groundwater has been taken place simultaneously in various places on this island in August to November 2007. Due to the nature of the island's aquifer which surrounded by marine environment, the possible source of chloride in groundwater in Pulau Tiga may be due to precipitation of marine aerosols and intrusion of saline water into the aquifer (Aris et al., 2006).

Nitrate concentration reveals a relatively low value with range from $3.70 \mathrm{mgl}^{-1}$ to $0.80 \mathrm{mgl}^{-1}$ for both sampling periods. Nitrate concentration in the area is far below the WHO permissible limit of $50 \mathrm{mgl}^{-1}$ (WHO, 2004). As a general observation, lower nitrate concentrations were observed during the sampling event in November 2007. A possible explanation for the diminution of nitrate in November 2007 may be due to the flushing of nitrate down the soil column and through the aquifer, and dilution of nitrate within the aquifer by heavy precipitation (Richerson \& Cole, 1999). Natural processes that may add nitrate to the groundwater include precipitation, mineral weathering, and decay of organic matter (Wynne et al., 1989). Hence, the range of nitrate contents in the samples reflects on the hydrogeochemical conditions in the aquifer, which result in "natural" nitrate concentrations between 0.80 and 3.70 $\mathrm{mgl}^{-1}$ as suggested by Kim et al., (2003).

\subsubsection{Cation constituents}

Potassium $\left(\mathrm{K}^{+}\right)$concentration varies with range from $1.36 \mathrm{mgl}^{-1}$ to $7.53 \mathrm{mgl}^{-1}$ for August sampling and between 0.90 $\mathrm{mgl}^{-1}$ to $3.790 \mathrm{mgl}^{-1}$ for November sampling as shown in Table 3. The $\mathrm{K}^{+}$concentration in the sample is less than the permissible limit $\left(200 \mathrm{mgl}^{-1}\right.$, WHO, 2004). Potassium may derived from the interaction of groundwater with the aquifer's matrix (high-Ca-calcite) which is very common in coastal aquifer (Appelo \& Postma, 2005), part of which may derived from seawater intrusion in the area (Al-Agha, 2004). The positive and significance correlation of $\mathrm{K}^{+}$with both $\mathrm{Cl}^{-}$and $\mathrm{SO}_{4}{ }^{2-}$ on August 2007 (Table 4) may be interpreted in the remnant of saline water intrusion as well (Aris et al., 2007).

Analyses of all groundwater samples show a low concentration of sodium $\left(\mathrm{Na}^{+}\right)$with concentrations below $10 \mathrm{mgl}^{-1}$. The sodium concentrations in all sampling stations were found to be relatively constant. Sodium concentrations recorded during August sampling were between $7.63 \mathrm{mgl}^{-1}$ to $8.12 \mathrm{mgl}^{-1}$. While second sampling on November 2007 (dry period) found that the sodium concentrations for all groundwater samples were range between $5.81 \mathrm{mgl}^{-1}$ to 7.59 $\mathrm{mgl}^{-1}$. Weak positive correlation between $\mathrm{Na}^{+}$and $\mathrm{Cl}^{-}$on November 2007 as shown in Table 5 suggests the groundwater might be influenced by marine sources such as result of rain water, sea-salt spray and marine deposits in a lesser extent. Dakin et al., (1983) calculated that $\mathrm{Na}^{+}$and $\mathrm{Cl}^{-}$could originate in the mudstone units on Pulau Tiga at concentrations that could support long-term release to the circulating groundwater, and be released by diffusion through sandstone and into the fractures over many thousands of years.

In the study area, dissolved magnesium $\left(\mathrm{Mg}^{2+}\right)$ is generally lower than calcium and sodium. Magnesium concentration in groundwater shows a narrow range from $3.31 \mathrm{mgl}^{-1}$ to $3.43 \mathrm{mgl}^{-1}$ in August and ranges from $1.70 \mathrm{mgl}^{-1}$ to $3.08 \mathrm{mgl}^{-1}$ for the re-sampling in November 2007. The groundwater's calcium concentration in Pulau Tiga is less than the WHO permissible limit $\left(200 \mathrm{mgl}^{-1}, \mathrm{WHO}, 2004\right)$. From the chemical analyses, calcium $\left(\mathrm{Ca}^{2+}\right)$ concentrations on August were 
between $42.85 \mathrm{mgl}^{-1}$ to $51.87 \mathrm{mgl}^{-1}$. During second sampling, the concentration values obtained were between 21.30 $\mathrm{mgl}^{-1}$ to $42.20 \mathrm{mgl}^{-1}$. Dissolution of carbonate minerals by fresh water is the main source of calcium, magnesium and bicarbonates, and water has a low content of dissolved solids. The calcium bicarbonate and magnesium calcium bicarbonate compositions usually coupled with TDS not more than $600 \mathrm{mgl}^{-1}$ and $\mathrm{pH}$ not exceeded 7.5 (Mokrik \& Baublyte, 2005). Besides, magnesium can be released upon weathering of olivines, pyroxenes and hornblende (van Sambeek et al., 2000).

\subsection{Hydrogeochemical facies}

The principal characters of the hydrochemical facies can be illustrated by methods similar to those used in lithofacies and geochemical studies - trilinear diagrams (Piper, 1944). From the Piper plot shown in Figure 6, it can be concluded that $80 \%$ of the five sampling sites on the island had $\mathrm{Ca}-\mathrm{HCO}_{3}$ water types. While the remaining $20 \%$ had $\mathrm{Ca}-\mathrm{Cl}$ water types as shown in Table 5. Based on Figure 5, apparently the groundwater is mainly fresh, as indicated by its $\mathrm{Ca}-\mathrm{HCO}_{3}$ water type. Large proportions of the groundwater showed $\mathrm{Ca}-\mathrm{HCO}_{3}$, which generally indicates a strong freshwater content in the aquifer (Aris et al., 2008). Conversely, the $\mathrm{Ca}-\mathrm{Cl}$ facies indicates the occurrence of active seawater intrusion (Gimenez \& Morell, 1997). The formation of $\mathrm{CaCl}_{2}$ waters is a result of progressive salinisation of the waters. The process of reverse cation exchange may create $\mathrm{CaCl}_{2}$ waters at higher salinities due to the removal of $\mathrm{Na}$ out of solution for bound $\mathrm{Ca}$. Alternatively, $\mathrm{CaCl}_{2}$ type waters could also be a result of the process of mixing between "younger" fresh water and saline older water (Adams, 2001). However, the Piper diagram elucidate that there is no significant changes in the hydrochemical facies in different seasons as shown in Figure 5. Such steady condition in the hydrochemical facies clearly reflects the homogeneity of the geological condition for the area (Leung et al., 2005). Table 6 summarized the general groundwater facies of each sampling periods and locations.

The groundwater components of Pulau Tiga were dominated by $\mathrm{Ca}^{2+}>\mathrm{Na}^{+}>\mathrm{Mg}^{2+}>\mathrm{K}^{+}$; and $\mathrm{HCO}_{3}{ }^{-}>\mathrm{Cl}^{-}>\mathrm{SO}_{4}{ }^{2-}>$ $\mathrm{NO}_{3}^{-}$, except station PT 3 where the dominant ions order is followed by $\mathrm{Ca}^{2+}>\mathrm{Na}^{+}>\mathrm{K}^{+}>\mathrm{Mg}^{2+}$; and $\mathrm{Cl}^{-}>\mathrm{HCO}_{3}^{-}>$ $\mathrm{SO}_{4}{ }^{2-}>\mathrm{NO}_{3}{ }^{-} . \mathrm{Ca}^{2+}$ and $\mathrm{HCO}_{3}^{-}$account $50 \%-70 \%$ of the ions. $\mathrm{HCO}_{3}^{-}$accounts around $53 \%$ of the total major ions in any given analysis depending on the well. While $\mathrm{Cl}^{-}$accounts around $29 \%$ of the total major ions. The percentage of ion distributions calculated using the following equation:

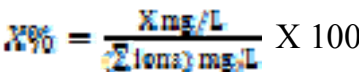

where $\mathrm{X}=$ specific ion $\left(\mathrm{Ca}^{2+}, \mathrm{Na}^{+}, \mathrm{Mg}^{2+}, \mathrm{K}^{+}, \mathrm{Cl}^{-}, \mathrm{HCO}_{3}{ }^{-}, \mathrm{NO}_{3}{ }^{-}\right.$or $\left.\mathrm{SO}_{4}{ }^{2-}\right)$, and ions = total for $\mathrm{Ca}^{2+}, \mathrm{Na}^{+}, \mathrm{Mg}^{2+}, \mathrm{K}^{+}, \mathrm{Cl}^{-}$, $\mathrm{HCO}_{3}^{-}, \mathrm{NO}_{3}^{-}$or $\mathrm{SO}_{4}{ }^{2-}$ (Aris et al., 2007).

\subsection{Statistical Analysis}

ANOVA analysis shows significant change in certain chemical composition of groundwater when the groundwater is sampled at different climatic conditions, it can be observed that the concentrations of main ions generally decrease in November 2007 at rainy season. This decrease may be due to the high contribution of rainwater in November which lead to flushing effect (dilution) and input of more fresh water into the aquifer. From the ANOVA analysis, $\mathrm{pH}$, temperature, EC, DO, salinity, TDS, $\mathrm{HCO}_{3}{ }^{-}, \mathrm{NO}_{3}{ }^{-}, \mathrm{SO}_{4}{ }^{2-}, \mathrm{Ca}^{2+}, \mathrm{Mg}^{2+}, \mathrm{K}^{+}$and $\mathrm{Na}^{+}$shows significant variations among dry and wet period. Conversely, both Eh values and $\mathrm{Cl}^{-}(r=0.838$, and $r=0.213$, respectively) do not show significant variations between seasons.

\section{Conclusions}

This study shows that the groundwater quality of Pulau Tiga is generally good in quality for domestic and other purposes with respect to the parameters considered. The water quality as well as the main chemical composition of groundwater, do change significantly when water sampled at dry and wet condition, this observation apparently indicates that climate has a significant influence on the water chemistry. Nevertheless, the amount of the rainwater component can be an important factor in some geochemical processes affecting the aqueous system, and therefore, climatic conditions should be considered when planning water sampling campaigns. A high rainwater contribution to the aquifer leads to a decrease in the concentration of many chemical species due to dilution processes. In this study, there are two types of groundwater identified on the basis of by water chemistry via trilinear diagrams. That is the $\mathrm{Ca}-\mathrm{HCO}_{3}$ and $\mathrm{Ca}-\mathrm{Cl}$ water types. The groundwater of Pulau Tiga is rather fresh, with chloride concentration varying between $50.48 \mathrm{mgl}^{-1}$ and $489.85 \mathrm{mgl}^{-1}$. The main possible source of chloride ions presents in the groundwater of Pulau Tiga may be remnant of seawater, the influence of sea spray and other marine sources. In PT 3, due to the encroachment of brackish tidal channel water into the aquifer, the salinity, TDS and chloride concentration increased. As a result, the water quality deteriorates. Generally, groundwater presents in shallow aquifers of all stations were good in quality and below potable limit as set by WHO (WHO, 2004). Since this is a baseline study, it is recommended that groundwater analysis be carried out frequently to monitor the rate and kind of contaminations. 


\section{References}

Adams, S., Titus, R., Pietersen, K., Tredoux, G. \& Harris, C., (2001). Hydrochemical characteristic s of aquifers near Sutherland in the Western Karoo, South Africa. Journal of Hydrology 241, 93-103.

Al-Agha, M.R., (2004). Hydrochemical Faciens of Groundwater in the Gaza Strip. Hydrol Sci-Journal-des-sciences Hydrologiques. 49, pg359-372.

Allen, D.M. \& Matsuo, G.P., (2002). Results of the groundwater geochemistry Study on Hornby Island, British Columbia. Final Report, Simon Fraser University \& Island Trust, Victoria, British Columbia.

Amadi, P.A., Ofoegbu C.O. \& Morrison, T., (1989). Hydrogeochemical assessment of groundwater quality in parts of the Niger Delta, Nigeria. Environ Geol Water Sci, 14(3): 195-202.

APHA, (American Public Health Association), (1995). Standard Methods for the Examination of Water and Wastewater. $19^{\text {th }}$ Ed. American Water Works Association, Water Environment Federation, Washington.

Appelo, C.A.J. \& Postma, D., (1993). Geochemistry Groundwater and Pollution. Balkema, Rotterdam, The Netherlands, pg 536.

Appelo, C.A.J., \& Postma, D., (2005). Geochemistry, Groundwater and Pollution. $2^{\text {nd }}$. Balkema, Rotterdam.

Aris, A.Z., Abdullah, M.H., \& Wong, K.K., (2006). Hydrochemical Analysis on Seawater Intrusion of Small Carbonate Islands; Manukan and Sipadan, Sabah. Proceedings of the $2^{\text {nd }}$ SANREM Conference, pg40-44.

Aris, A.Z., Abdullah, M.H., \& Kim, K.W., (2007). Hydrogeochemistry of Groundwater in Manukan Island, Sabah. The Malaysian Journal of Analytical Sciences, 11(2), pg407-413.

Aris, A.Z., Abdullah, M.H., Kim, K.W. \& Praveena, S.M., (2008). Hydrochemical Changes in a Small Tropical Island's Aquifer: Manukan Isalnd, Sabah, Malaysia. Environ Geol, DOI 10.1007/s00254-008-1275-3.

Chadha, D.K., (1999). A Proposed New Diagram for Geochemical Classification of Natural Waters and Interpretation of Chemical Data. Hydrogeology Journal, 7, pg431-439.

Cidu, R., Biddau, R., Manca, F. \& Piras, M., (2006). Hydrogeochemical Features of the Sardinian Rivers. Per Mineral 76(1), pg41-57.

Dakin, R.A., Farvolden, J.A., Cherry, J.A. \& Fritz, P., (1983). “Origin of dissolved solids in groundwater of Mayne Island, British Columbia, Canada, Journal of Hydrology, 63, 233-270, 1983.

Drever, J.I., (1997). The geochemistry of Natural Waters: Surface and Groundwater Environments. $3^{\text {rd }}$ Ed. Prentice-Hall, New Jersey.

Fernandes, P.G., Bahir, M., Mendonca, Carreira, P., Fakir \& Silva, M.O., (2005). Anthropogenic features in the Sines (Portugal) and Essaouira (Morocco) Coastal aquifers: A comparative study of their hydrochemical evolution by a principal component analysis. Estudios Geol., 61, pg 207-219.

Gimenez, E. \& Morell, I., (1997). Hydrogeochemical analysis of salinization processes in the coastal aquifer of Oropesa (Castellon, Spain). Environmental Geology, 29, pg 118 - pg 131.

Gonzalez, L.N., Gonzalez, A., Tume, P. \& Silva, A., (2001). Hydrogeochemistry and Behavior of Groundwater in the Rio Laja Basin, Bio-Bio Region, Chile. $7^{\text {th }}$ International Conference on Environmenta Science and Technology, Ermoupolis, Syros Island, Greece, pg268-274.

Hem, J.D., (1970). Study and interpretation of the chemical characteristics of natural water. US Geol.Surv.Water Supply Pap. 1473, pp. 363.

Kim, J.H., Yum, B.W., Kim, R.H., Koh, D.C., Cheong, T.J., Lee, J.H. \& Chang, H.W., (2003). Application of Cluster Analysis for the Hydrogeochemical Factors of Saline Groundwater in Kimje, Korea. Geosciences Journal 7(4), pg313-322.

Leung, C.M., Jiao, J.J., Malpus, J., Chan, W.T., Wang, Y.X., (2005). Factors Affecting the Groundwater Chemistry in a Highly Urbanized Costal Area in Hong Kong: an Example from the Mid-Levels Area. Environ Geol 48, pg480-495.

Mokrik, R., \& Baublyte, A., (2005). Water Geochemistry in the Sventoji-Arukula Aquifer System, Lithuania. Geologija. 52 ,pg 55-64.

Mondal, N.C., Singh, V.S., Saxena V.K. \& Prasad, R.K., (2007). Improvement of Groundwater Quality due to Fresh Water Ingress in Potharlanka Island, Krishna Delta, India. Environ Geol, DOI 10.1007/s 00254-007-1010-5.

Park, S.C., Yun S.T., Chae G.T., Yoo I.S., Shin K.S., Heo C.H. \& Lee S.K., (2005). Regional Hydrochemical Study on Salinization of Coastal Aquifers, Western Coastal Area of South Korea. Journal of Hydrology 313, pg182-194. 
Piper, A.M., (1944). A Graphical procedure in the geochemical interpretation of water analysis: American Geophysical Union Trans., 25, p.914-923.

Richerson, P., \& Cole, D., (2000). April 1999 Milton-Freewater Groundwater Quality Study. Department of Environmental Quality, State of Oregon

Sanudin, H.T., Sahibin, A.R., \& Baba, M., (1999). Geology Pulau Tiga, Universiti Malaysia Sabah.

van Sambeek, M.H.G., Eggenkamp, H.G.M., \& Vissers, M.J.M., (2000). The Groundwater Quality of Aruba, Bonaire and Cutacao: a Hydrogeochemical Study. Geologie en Mijnbouw/ Netherlands Journal of Geosciences 79(4), pp $459-466$.

WHO (World Health Organization), (2004). Guideliness for Drinking-water quality. Volume 1 Recommendations. $3^{\text {rd }}$ Ed. World Health Organization, Geneva.

Wynne, J.B., Hopkins, P., Houchins, J.O., Beinke, A., (1989). Groundwater quality of Texas - An overview of natural and man-affected conditions. Report 89-01. Texas Water Commision.

Table 1. The hydrogeological data, station features and GPS location of each station in Pulau Tiga

\begin{tabular}{|c|c|c|}
\hline Station Code & GPS Location & Well's Features \\
\hline \multirow[t]{5}{*}{ PT 1} & $05^{\circ} 43^{\prime} 12.2^{\prime \prime} \mathrm{N}$ & Year of Construction $=1981$ \\
\hline & $115^{\circ} 39^{\prime} 01.1 ” \mathrm{E}$ & Well's Diameter $=1 \times 1 \mathrm{~m}$ \\
\hline & & Water Table $=1.07 \mathrm{~m}$ \\
\hline & & Screen $=$ Cement and pebbles \\
\hline & & Distance from Shoreline $=50 \mathrm{~m}$ \\
\hline \multirow[t]{5}{*}{ PT 2} & $05^{\circ} 43^{\prime} 12.6^{\prime \prime} \mathrm{N}$ & Year of Construction $=1985$ \\
\hline & $115^{\circ} 39^{\prime} 01.6^{\prime \prime} \mathrm{E}$ & Well's Diameter $=1.5 \times 1.5 \mathrm{~m}$ \\
\hline & & Water Table $=1.24 \mathrm{~m}$ \\
\hline & & Screen $=$ Cement and pebbles \\
\hline & & Distance from Shoreline $=57 \mathrm{~m}$ \\
\hline \multirow[t]{5}{*}{ PT 3} & $05^{\circ} 43^{\prime} 13.4^{\prime \prime} \mathrm{N}$ & Year of Construction $=2004$ \\
\hline & $115^{\circ} 39^{\prime} 02.9^{\prime \prime} \mathrm{E}$ & Well's Diameter $=1.53 \times 1.53 \mathrm{~m}$ \\
\hline & & Water Table $=0.93 \mathrm{~m}$ \\
\hline & & Screen $=$ Cement and red brick \\
\hline & & Distance from Shoreline $\approx 95.5 \mathrm{~m}$ \\
\hline \multirow[t]{5}{*}{ PT 4} & $05^{\circ} 43^{\prime} 19.5^{\prime \prime} \mathrm{N}$ & Year of Construction $=1999$ \\
\hline & $115^{\circ} 38^{\prime} 55.33^{\prime \prime} \mathrm{E}$ & Well's Diameter $=$ Electrical Pump \\
\hline & & Water Table $=1.53 \mathrm{~m}$ \\
\hline & & Screen $=$ Plastic ring \\
\hline & & Distance from Shoreline $=60 \mathrm{~m}$ \\
\hline \multirow[t]{5}{*}{ PT 5} & $05^{\circ} 43^{\prime} 23.8^{\prime \prime} \mathrm{N}$ & Year of Construction $=2006$ \\
\hline & $115^{\circ} 38^{\prime} 49.3 ” \mathrm{E}$ & Well's Diameter $=1.3 \times 1.3 \mathrm{~m}$ \\
\hline & & Water Table $=0.54 \mathrm{~m}$ \\
\hline & & Screen $=$ Cement ring \\
\hline & & Distance from Shoreline $=45 \mathrm{~m}$ \\
\hline
\end{tabular}


Table 2. Pulau Tiga first sampling (August 2007) in-situ data

\begin{tabular}{|c|c|c|c|c|c|c|c|c|}
\hline \multirow{11}{*}{ 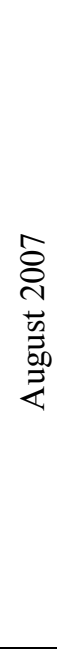 } & Station Code & $\mathrm{pH}$ & $\begin{array}{c}\text { Temp. } \\
\left({ }^{\circ} \mathrm{C}\right)\end{array}$ & $\begin{array}{c}\text { Cond. } \\
\left(\mu \mathrm{Scm}^{-1}\right)\end{array}$ & $\begin{array}{c}\text { DO } \\
\left(\mathrm{mgl}^{-1}\right)\end{array}$ & $\begin{array}{l}\text { Sal. } \\
\text { (ppt) }\end{array}$ & $\begin{array}{c}\text { Eh } \\
(\mathrm{mV})\end{array}$ & $\begin{array}{c}\text { TDS } \\
(\mathrm{ppm})\end{array}$ \\
\hline & PT 1 & 6.84 & 28.80 & 956.00 & 2.00 & 0.50 & -24.00 & 476.00 \\
\hline & PT 2 & 6.84 & 28.80 & 861.00 & 2.06 & 0.40 & -26.00 & 430.00 \\
\hline & PT 3 & 7.27 & 28.60 & 999.00 & 1.84 & 0.50 & -47.00 & 499.00 \\
\hline & PT 4 & 6.98 & 29.90 & 987.00 & 1.08 & 0.50 & -30.00 & 490.00 \\
\hline & PT 5 & 7.08 & 29.80 & 1005.00 & 1.53 & 0.50 & -34.00 & 502.00 \\
\hline & Mean & 7.01 & 29.18 & 961.60 & 1.70 & 0.48 & -32.20 & 479.33 \\
\hline & St. Dev. & 0.16 & 0.57 & 54.93 & 0.37 & 0.04 & 8.44 & 27.36 \\
\hline & Median & 6.98 & 28.80 & 987.00 & 1.84 & 0.50 & -30.00 & 490.00 \\
\hline & Maximum & 7.27 & 29.90 & 1005.00 & 2.06 & 0.50 & -24.00 & 502.00 \\
\hline & Minimum & 6.84 & 28.60 & 861.00 & 1.08 & 0.40 & -47.00 & 429.00 \\
\hline \multirow{10}{*}{ 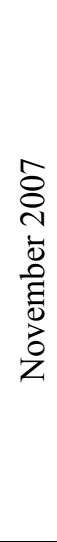 } & PT 1 & 6.93 & 27.70 & 817.00 & 4.20 & 0.40 & -28.00 & 412.00 \\
\hline & PT 2 & 7.13 & 27.70 & 828.00 & 4.22 & 0.40 & -37.00 & 414.00 \\
\hline & PT 3 & 6.86 & 27.60 & 505.00 & 4.69 & 0.20 & -23.00 & 253.00 \\
\hline & PT 4 & 7.33 & 27.40 & 786.00 & 6.01 & 0.40 & -46.00 & 393.00 \\
\hline & PT 5 & 6.94 & 26.90 & 330.00 & 5.69 & 0.10 & -23.00 & 165.00 \\
\hline & Mean & 7.04 & 27.45 & 653.13 & 4.96 & 0.30 & -31.53 & 327.40 \\
\hline & St. Dev. & 0.19 & 0.31 & 207.88 & 0.78 & 0.13 & 9.26 & 104.58 \\
\hline & Median & 6.93 & 27.60 & 786.00 & 4.69 & 0.40 & -28.00 & 393.00 \\
\hline & Maximum & 7.35 & 27.70 & 828.00 & 6.12 & 0.40 & -21.00 & 416.00 \\
\hline & Minimum & 6.86 & 26.70 & 329.00 & 4.20 & 0.10 & -46.00 & 164.00 \\
\hline \multicolumn{2}{|c|}{ WHO limits (2004) } & $6.5-8.5$ & & 1400.00 & & & & \\
\hline
\end{tabular}


Table 3. Average value of major anion-cation $\left(\mathrm{mg} \mathrm{l}^{-1}\right)$ of groundwater at different sampling locations and period along with WHO (2004) maximum permissible level

\begin{tabular}{|c|c|c|c|c|c|c|c|c|c|}
\hline \multirow{11}{*}{ 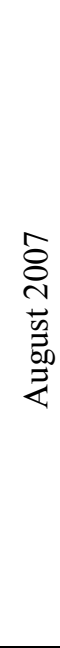 } & $\begin{array}{c}\text { Sampling } \\
\text { Station }\end{array}$ & $\begin{array}{l}\mathrm{HCO}_{3}^{-} \\
\left(\mathrm{mgl}^{-1}\right)\end{array}$ & $\begin{array}{c}\mathrm{NO}_{3}^{-} \\
\left(\mathrm{mgl}^{-1}\right)\end{array}$ & $\begin{array}{l}\mathrm{SO}_{4}^{2-} \\
\left(\mathrm{mgl}^{-1}\right)\end{array}$ & $\begin{array}{c}\mathrm{Cl}^{-} \\
\left(\mathrm{mgl}^{-1}\right)\end{array}$ & $\begin{array}{c}\mathrm{Ca}^{2+} \\
\left(\mathrm{mgl}^{-1}\right)\end{array}$ & $\begin{array}{l}\mathrm{Mg}^{2+} \\
\left(\mathrm{mgl}^{-1}\right)\end{array}$ & $\begin{array}{c}\mathrm{K}^{+} \\
\left(\mathrm{mgl}^{-1}\right)\end{array}$ & $\begin{array}{c}\mathrm{Na}^{+} \\
\left(\mathrm{mgl}^{-1}\right)\end{array}$ \\
\hline & PT 1 & 284.00 & 3.30 & 31.00 & 147.08 & 49.26 & 3.43 & 1.40 & 7.75 \\
\hline & PT 2 & 289.00 & 3.00 & 25.00 & 101.17 & 48.48 & 3.36 & 1.75 & 7.92 \\
\hline & PT 3 & 205.00 & 1.60 & 79.00 & 266.95 & 43.22 & 3.41 & 7.39 & 7.89 \\
\hline & PT 4 & 327.00 & 1.50 & 34.00 & 145.43 & 51.48 & 3.33 & 2.55 & 7.92 \\
\hline & PT 5 & 322.00 & 2.10 & 32.00 & 149.65 & 51.41 & 3.32 & 2.36 & 8.29 \\
\hline & Average & 285.13 & 2.30 & 40.07 & 160.06 & 48.77 & 3.37 & 7.95 & 3.09 \\
\hline & St. Dev. & 45.61 & 0.78 & 20.30 & 50.83 & 3.14 & 0.05 & 0.32 & 2.27 \\
\hline & Median & 285.00 & 2.10 & 32.00 & 142.68 & 49.23 & 3.35 & 7.90 & 2.37 \\
\hline & Maximum & 330.00 & 3.70 & 82.00 & 287.84 & 51.87 & 3.43 & 8.89 & 7.53 \\
\hline & Minimum & 203.00 & 1.40 & 25.00 & 98.97 & 42.85 & 3.31 & 7.59 & 1.35 \\
\hline \multirow{10}{*}{$\begin{array}{l}\hat{8} \\
\text { d } \\
\overline{0} \\
\bar{E} \\
0 \\
0 \\
0\end{array}$} & PT 1 & 217.00 & 1.60 & 20.30 & 73.15 & 40.93 & 3.06 & 1.00 & 7.47 \\
\hline & PT 2 & 272.00 & 1.80 & 19.70 & 68.98 & 41.39 & 3.01 & 0.98 & 7.34 \\
\hline & PT 3 & 120.00 & 1.80 & 41.00 & 241.42 & 22.26 & 2.44 & 3.51 & 7.29 \\
\hline & PT 4 & 287.00 & 1.00 & 20.30 & 57.65 & 41.21 & 2.88 & 1.75 & 7.44 \\
\hline & PT 5 & 125.00 & 1.20 & 3.00 & 54.98 & 22.37 & 1.84 & 1.47 & 6.08 \\
\hline & Average & 217.67 & 1.48 & 20.87 & 115.80 & 33.63 & 2.65 & 7.12 & 1.74 \\
\hline & St. Dev & 80.65 & 0.37 & 12.75 & 120.99 & 9.61 & 0.48 & 0.56 & 0.98 \\
\hline & Medium & 273.00 & 1.50 & 21.00 & 68.98 & 39.86 & 2.90 & 7.36 & 1.49 \\
\hline & Maximum & 293.00 & 1.90 & 42.00 & 489.85 & 42.20 & 3.08 & 7.59 & 3.79 \\
\hline & Minimum & 119.00 & 0.80 & 3.00 & 50.48 & 21.30 & 1.70 & 5.81 & 0.90 \\
\hline \multicolumn{2}{|c|}{ WHO limits (2004) } & & 50.00 & 400.00 & 250.00 & 200.00 & 100.00 & 200.00 & \\
\hline
\end{tabular}

Table 4. Correlation coefficient matrix of analysed parameters for August 2007

\begin{tabular}{|c|c|c|c|c|c|c|c|c|c|c|c|c|c|c|c|c|}
\hline Dry & $\mathrm{pH}$ & Temp & EC & $\mathrm{DO}$ & Salinity & $\mathrm{mV}$ & ORP & TDS & $\mathrm{HCO}_{3}{ }^{-}$ & $\mathrm{NO}_{3}{ }^{-}$ & $\mathrm{SO}_{4}{ }^{2-}$ & $\mathrm{Cl}^{-}$ & $\mathrm{Ca}^{2+}$ & $\mathrm{Mg}^{2+}$ & $\mathrm{K}^{+}$ & $\mathrm{Na}^{+}$ \\
\hline $\mathrm{pH}$ & 1.000 & 0.584 & $0.000^{* *}$ & 0.058 & 0.196 & $0.000^{* *}$ & 0.723 & $0.000^{* *}$ & 0.641 & $0.002^{* * *}$ & $0.002^{* * *}$ & 0.141 & 0.642 & 0.187 & $0.000^{* *}$ & 0.268 \\
\hline Temp & -0.154 & 1.000 & 0.585 & $0.007^{* *}$ & 0.518 & 0.584 & 0.264 & 0.585 & $0.000^{* *}$ & 0.408 & 0.604 & 0.224 & $0.000^{* *}$ & $0.002^{* *}$ & 0.858 & 0.312 \\
\hline EC & 0.797 & 0.153 & 1.000 & $0.004^{* *}$ & $0.003^{* *}$ & $0.000^{* *}$ & 0.724 & $0.000^{* *}$ & 0.483 & $0.032^{*}$ & $0.005^{* *}$ & 0.206 & 0.282 & 0.120 & $0.020^{*}$ & 0.301 \\
\hline DO & -0.500 & -0.667 & -0.697 & 1.000 & $0.003^{* *}$ & 0.058 & 0.723 & $0.004^{* *}$ & $0.013^{*}$ & $0.001^{* *}$ & $0.024^{*}$ & 0.217 & $0.013^{*}$ & $0.013^{*}$ & $0.021^{*}$ & 0.389 \\
\hline Salinity & 0.354 & 0.181 & 0.705 & -0.707 & 1.000 & 0.196 & $0.003^{* *}$ & $0.003^{* *}$ & 0.490 & 0.113 & $0.004^{* *}$ & $0.004^{* *}$ & 0.263 & 1.000 & 0.205 & 0.785 \\
\hline $\mathrm{mV}$ & -1.000 & 0.154 & -0.797 & 0.500 & -0.354 & 1.000 & 0.723 & $0.000^{* *}$ & 0.641 & $0.002^{* *}$ & $0.002^{* *}$ & 0.141 & 0.642 & 0.187 & $0.000^{* *}$ & 0.268 \\
\hline ORP & -0.100 & -0.308 & 0.100 & -0.100 & 0.707 & 0.100 & 1.000 & 0.724 & 0.285 & 0.985 & 0.094 & $0.001^{* *}$ & 0.483 & $0.008^{* *}$ & 1.000 & 0.078 \\
\hline TDS & 0.798 & 0.153 & 0.994 & -0.698 & 0.705 & -0.798 & 0.100 & 1.000 & 0.517 & $0.030^{*}$ & $0.005^{* *}$ & 0.195 & 0.276 & 0.109 & $0.020^{*}$ & 0.198 \\
\hline $\mathrm{HCO}_{3}^{-}$ & -0.131 & 0.937 & 0.196 & -0.624 & 0.193 & 0.131 & -0.295 & 0.182 & 1.000 & 0.428 & 0.565 & 0.255 & $0.000^{* *}$ & $0.005^{* *}$ & 0.703 & 0.642 \\
\hline $\mathrm{NO}_{3}^{-}$ & -0.735 & -0.231 & -0.556 & 0.746 & -0.427 & 0.735 & -0.005 & -0.560 & -0.221 & 1.000 & $0.004^{* *}$ & 0.089 & 0.651 & 0.080 & $0.000^{* *}$ & 0.628 \\
\hline $\mathrm{SO}_{4}{ }^{2-}$ & 0.732 & -0.146 & 0.679 & -0.579 & 0.696 & -0.732 & 0.448 & 0.679 & -0.161 & -0.697 & 1.000 & $0.001^{* *}$ & 0.950 & 0.894 & $0.002^{* *}$ & 1.000 \\
\hline $\mathrm{Cl}^{-}$ & 0.399 & -0.334 & 0.347 & -0.339 & 0.696 & -0.399 & 0.782 & 0.354 & -0.314 & -0.454 & 0.776 & 1.000 & 0.270 & 0.195 & $0.048^{*}$ & 0.344 \\
\hline $\mathrm{Ca}^{2+}$ & -0.131 & 0.901 & 0.297 & -0.622 & 0.309 & 0.131 & -0.196 & 0.301 & 0.834 & -0.127 & -0.180 & -0.304 & 1.000 & $0.012^{*}$ & 0.594 & 0.221 \\
\hline $\mathrm{Mg}^{2+}$ & -0.360 & -0.739 & -0.419 & 0.622 & 0.000 & 0.360 & 0.655 & -0.430 & -0.687 & 0.466 & 0.038 & 0.355 & -0.631 & 1.000 & 0.216 & $0.019^{*}$ \\
\hline $\mathrm{K}^{+}$ & 0.884 & -0.050 & 0.591 & -0.589 & 0.347 & -0.884 & 0.000 & 0.593 & -0.107 & -0.846 & 0.739 & 0.517 & -0.150 & -0.340 & 1.000 & 0.524 \\
\hline $\mathrm{Na}^{+}$ & 0.306 & 0.280 & 0.286 & -0.240 & -0.077 & -0.306 & -0.469 & 0.352 & 0.131 & -0.136 & 0.000 & -0.263 & 0.336 & -0.595 & 0.179 & 1.000 \\
\hline
\end{tabular}

** Represents correlation is significant at the 0.01 level (2-tailed);

* Represents correlation is significant at the 0.05 level (2-tailed) 
Table 5. Correlation coefficient matrix of analysed parameters for November 2007

\begin{tabular}{|c|c|c|c|c|c|c|c|c|c|c|c|c|c|c|c|c|}
\hline Wet & $\mathrm{pH}$ & Temp & EC & DO & Salinity & $\mathrm{mV}$ & ORP & TDS & $\mathrm{HCO}_{3}{ }^{-}$ & $\mathrm{NO}_{3}{ }^{-}$ & $\mathrm{SO}_{4}{ }^{2-}$ & $\mathrm{Cl}^{-}$ & $\mathrm{Ca}^{2+}$ & $\mathrm{Mg}^{2+}$ & $\mathrm{K}^{+}$ & $\mathrm{Na}^{+}$ \\
\hline $\mathrm{pH}$ & 1.000 & 0.872 & $0.050^{*}$ & 0.305 & $0.003^{* *}$ & $0.000^{* *}$ & 0.752 & 0.079 & $0.002^{* *}$ & 0.305 & 0.696 & 0.060 & $0.006^{* *}$ & 0.163 & 0.413 & 0.099 \\
\hline Temp & 0.045 & 1.000 & $0.000^{* *}$ & $0.000^{* *}$ & $0.010^{* *}$ & 0.668 & 0.523 & $0.000^{* *}$ & 0.431 & $0.004^{* *}$ & 0.119 & $0.010^{* *}$ & 0.081 & $0.000^{* *}$ & 0.065 & $0.025^{*}$ \\
\hline EC & 0.514 & 0.789 & 1.000 & $0.018^{*}$ & $0.000^{* *}$ & $0.039^{*}$ & 0.718 & $0.000^{* *}$ & $0.047^{*}$ & 0.054 & 0.506 & 0.370 & $0.001^{* *}$ & $0.000^{* *}$ & $0.015^{*}$ & $0.023^{*}$ \\
\hline DO & 0.284 & -0.855 & -0.601 & 1.000 & 0.224 & 0.351 & 0.486 & $0.012^{*}$ & 0.954 & $0.002^{* *}$ & 0.480 & $0.015^{*}$ & 0.449 & $0.004^{* *}$ & $0.010^{* *}$ & 0.328 \\
\hline Salinity & 0.714 & 0.643 & 0.892 & -0.334 & 1.000 & $0.001^{* *}$ & 0.426 & $0.000^{* *}$ & $0.001^{* *}$ & 0.479 & 0.428 & 0.649 & $0.000^{* *}$ & $0.000^{* *}$ & 0.101 & $0.002^{* *}$ \\
\hline $\mathrm{mV}$ & -0.983 & -0.121 & -0.536 & -0.259 & -0.743 & 1.000 & 0.436 & 0.063 & $0.003^{* *}$ & 0.455 & 0.985 & 0.175 & $0.012^{*}$ & 0.143 & 0.548 & 0.085 \\
\hline ORP & -0.089 & -0.179 & -0.102 & -0.195 & -0.222 & 0.218 & 1.000 & 0.763 & 0.540 & 0.508 & $0.000^{* *}$ & 0.051 & 0.980 & 0.969 & $0.007^{* *}$ & 0.207 \\
\hline TDS & 0.468 & 0.855 & 0.964 & -0.632 & 0.889 & -0.490 & -0.085 & 1.000 & $0.032^{*}$ & 0.092 & 0.509 & 0.339 & $0.000^{* *}$ & $0.000^{* *}$ & $0.016^{*}$ & $0.005^{* *}$ \\
\hline $\mathrm{HCO}_{3}^{-}$ & 0.730 & 0.220 & 0.520 & -0.016 & 0.773 & -0.706 & 0.172 & 0.554 & 1.000 & 0.395 & 0.435 & 0.299 & $0.016^{*}$ & $0.013^{* *}$ & 0.102 & 0.067 \\
\hline $\mathrm{NO}_{3}{ }^{-}$ & -0.284 & 0.693 & 0.507 & -0.733 & 0.198 & 0.209 & -0.185 & 0.450 & -0.237 & 1.000 & $0.119^{\mathrm{a}}$ & $0.005^{* *}$ & 0.995 & 0.206 & 0.443 & 0.934 \\
\hline $\mathrm{SO}_{4}{ }^{2-}$ & -0.110 & 0.420 & 0.186 & -0.198 & 0.221 & -0.005 & -0.792 & 0.185 & -0.218 & 0.420 & 1.000 & $0.003^{* *}$ & 0.980 & 0.467 & 0.170 & 0.108 \\
\hline $\mathrm{Cl}^{-}$ & -0.496 & 0.641 & 0.250 & -0.614 & 0.128 & 0.369 & -0.511 & 0.165 & -0.288 & 0.681 & 0.717 & 1.000 & 0.554 & 0.229 & 0.751 & 0.423 \\
\hline $\mathrm{Ca}^{2+}$ & 0.675 & 0.465 & 0.778 & -0.212 & 0.805 & -0.629 & -0.007 & 0.817 & 0.609 & 0.002 & 0.007 & -0.166 & 1.000 & $0.002^{* *}$ & 0.062 & $0.002^{* *}$ \\
\hline $\mathrm{Mg}^{2+}$ & 0.380 & 0.841 & 0.887 & -0.694 & 0.878 & -0.397 & -0.011 & 0.933 & 0.621 & 0.346 & 0.203 & 0.331 & 0.721 & 1.000 & $0.010^{*}$ & $0.001^{* *}$ \\
\hline $\mathrm{K}^{+}$ & -0.229 & -0.487 & -0.615 & 0.643 & -0.440 & 0.169 & -0.662 & -0.608 & -0.438 & -0.214 & 0.374 & 0.089 & -0.493 & -0.642 & 1.000 & 0.516 \\
\hline $\mathrm{Na}^{+}$ & 0.442 & 0.575 & 0.582 & -0.271 & 0.732 & -0.459 & -0.345 & 0.685 & 0.485 & -0.024 & 0.432 & 0.223 & 0.721 & 0.746 & -0.182 & 1.000 \\
\hline
\end{tabular}

** Represents correlation is significant at the 0.01 level (2-tailed);

* Represents correlation is significant at the 0.05 level (2-tailed)

Table 6. Water types of Pulau Tiga

\begin{tabular}{cccccc}
\hline & PT 1 & PT 2 & PT 3 & PT 4 & PT 5 \\
\hline August 2007 & $\mathrm{Ca}-\mathrm{HCO}_{3}$ & $\mathrm{Ca}-\mathrm{HCO}_{3}$ & $\mathrm{Ca}-\mathrm{Cl}$ & $\mathrm{Ca}-\mathrm{HCO}_{3}$ & $\mathrm{Ca}-\mathrm{HCO}_{3}$ \\
November 2007 & $\mathrm{Ca}-\mathrm{HCO}_{3}$ & $\mathrm{Ca}-\mathrm{HCO}_{3}$ & $\mathrm{Ca}-\mathrm{Cl}$ & $\mathrm{Ca}-\mathrm{HCO}_{3}$ & $\mathrm{Ca}-\mathrm{HCO}_{3}$ \\
\hline
\end{tabular}

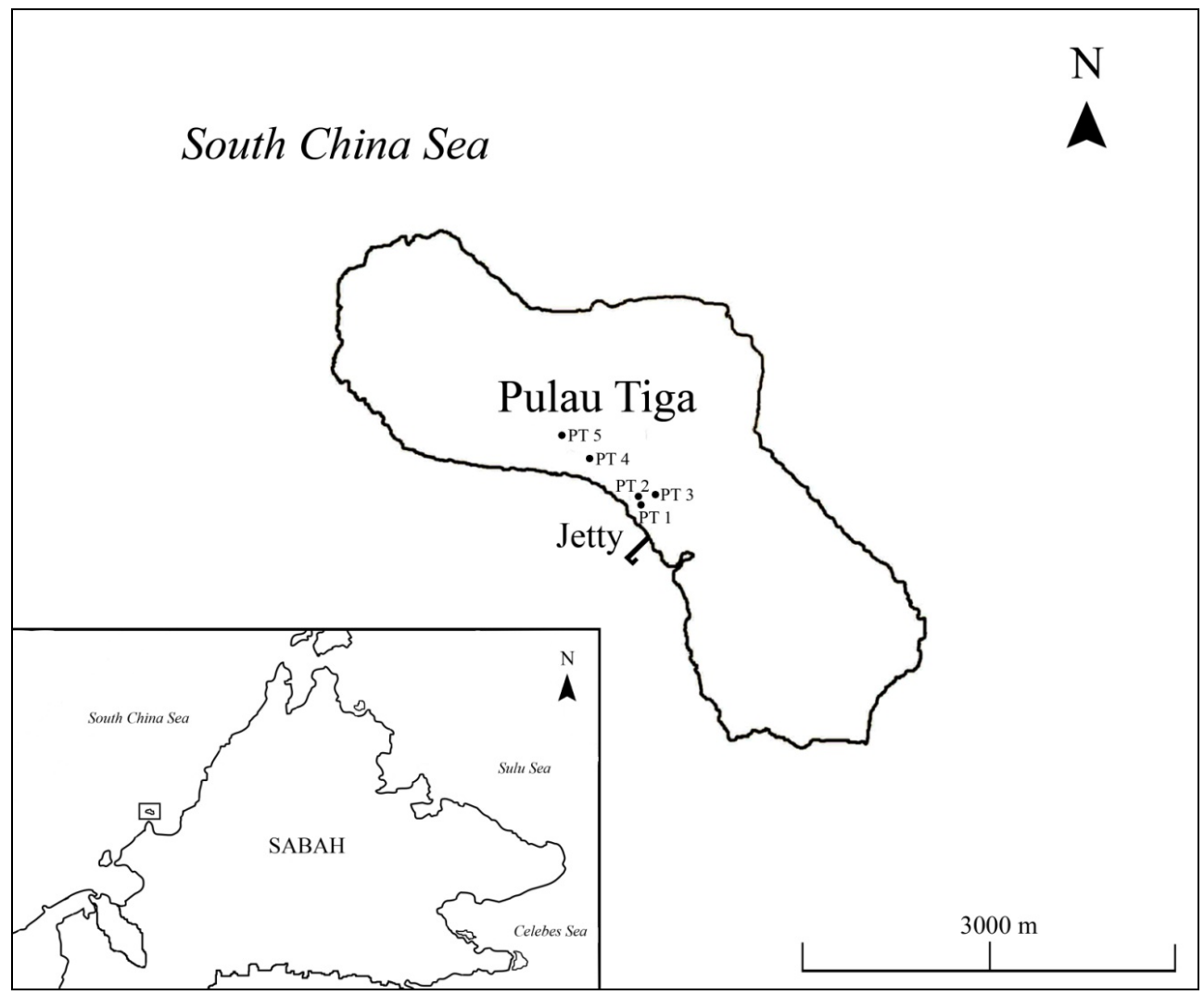

Figure 1. Schematic map showing the geographical locality of Pulau Tiga and its sampling locations 
Yearly Precipitation For Kuala Penyu

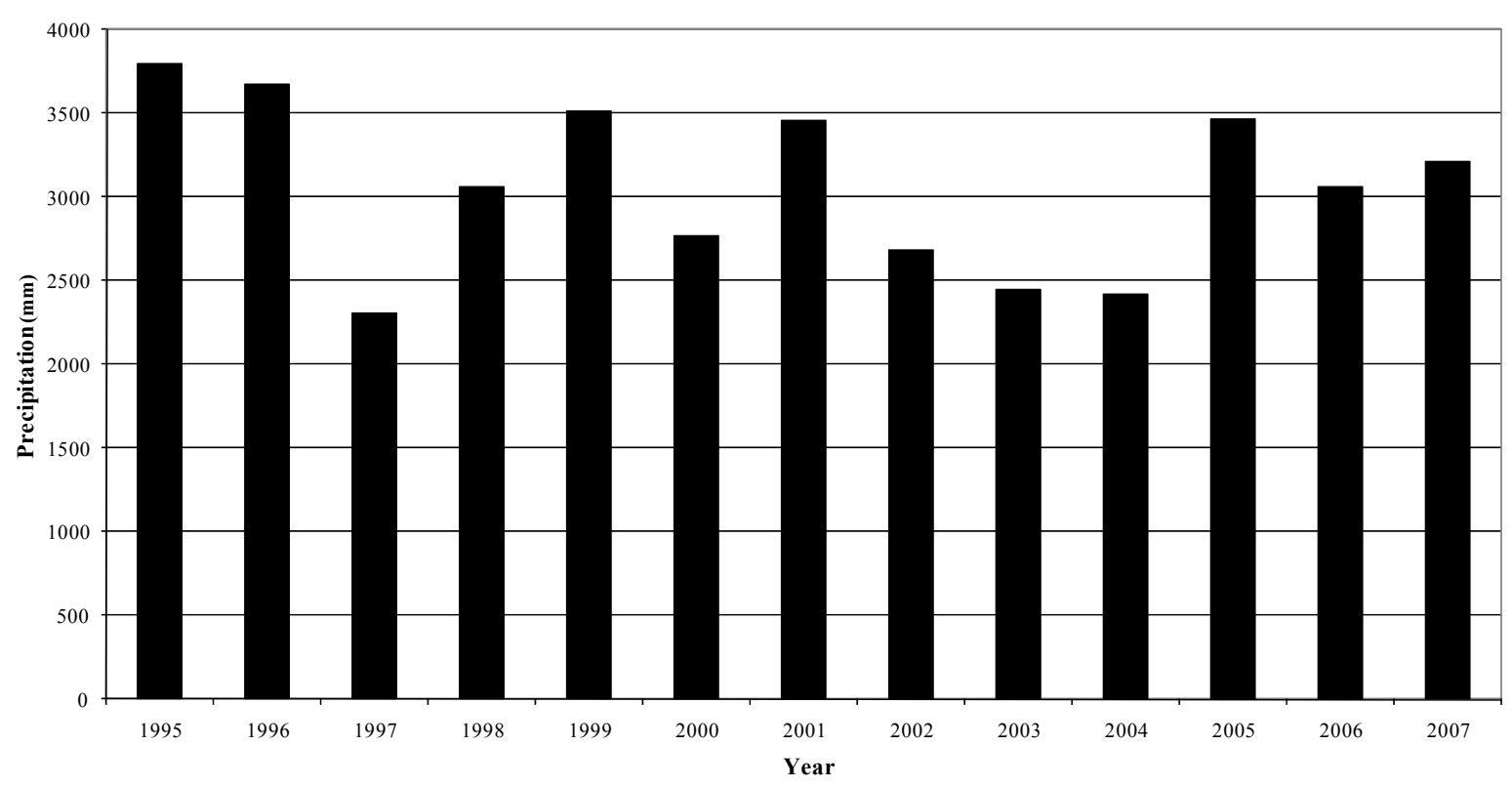

Figure 2. The average annual rainfall of Pulau Tiga for 1995 - 2007 (Sabah Meteorology Department, 2008)

Monthly Precipitation For Kuala Penyu (2007)

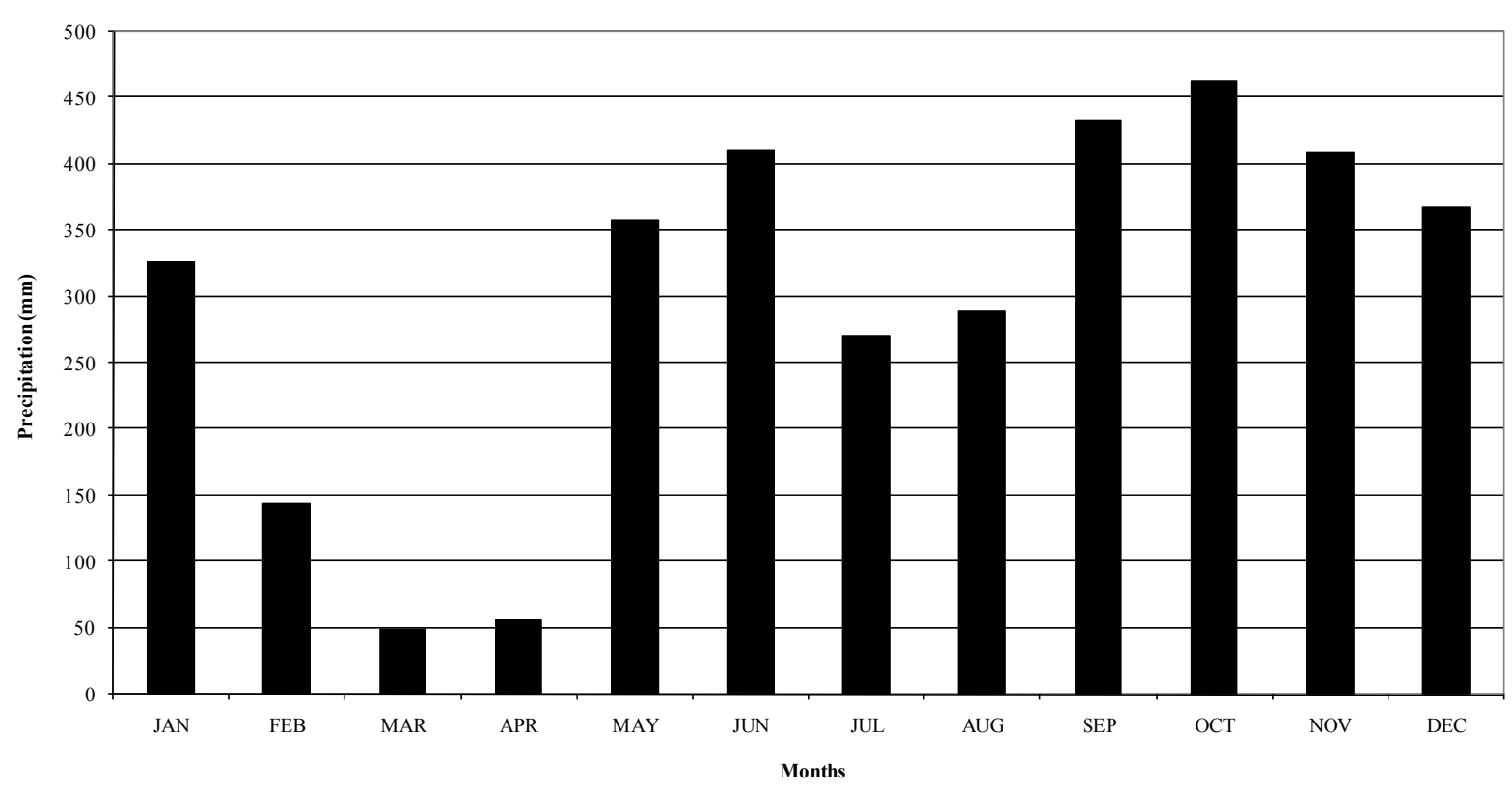

Figure 3. The average monthly rainfall on Pulau Tiga for 2007 (Sabah Meteorology Department, 2008) 


\section{Chloride vs. Sulfate}

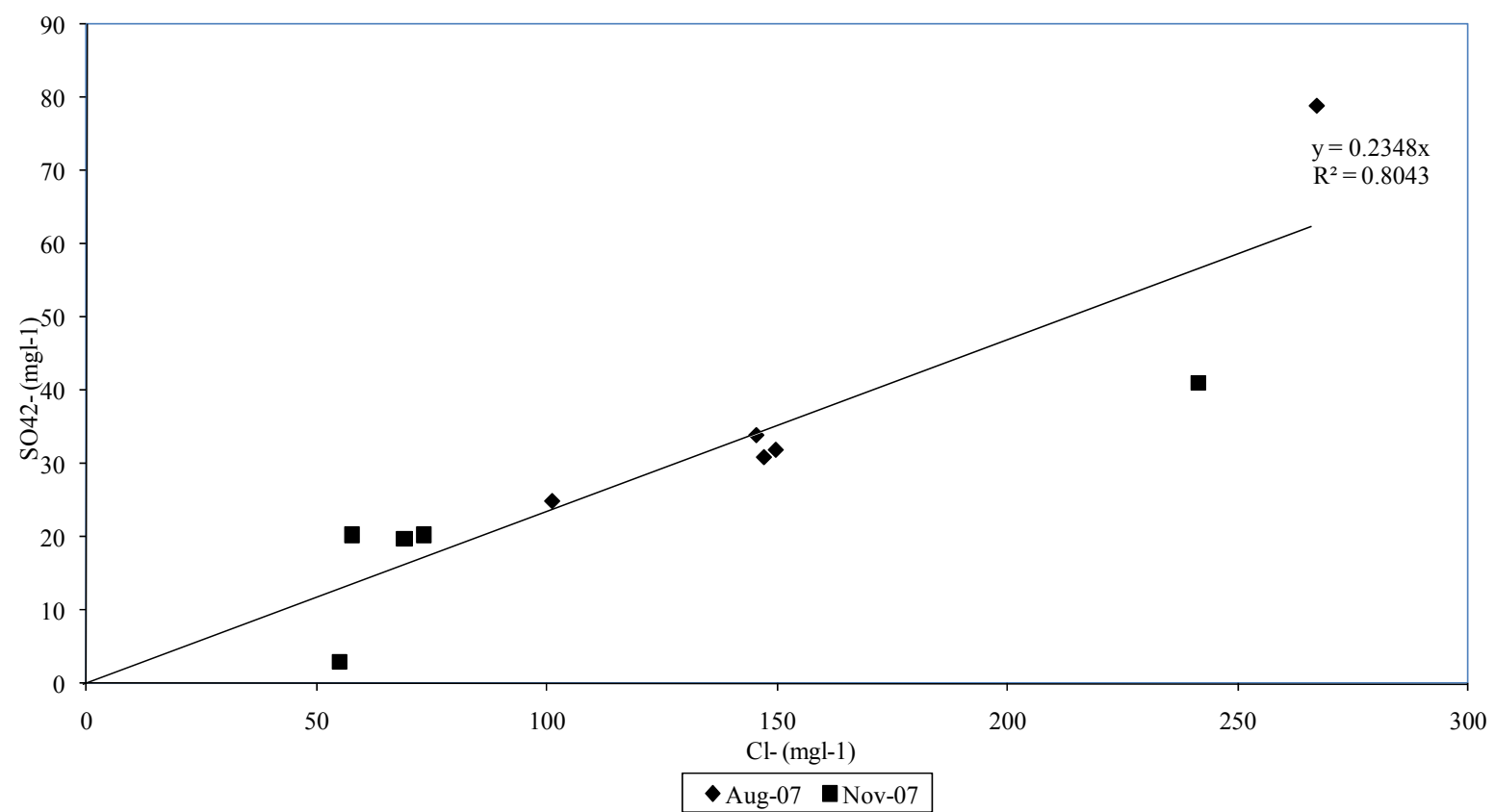

Figure 4. The dissolved $\mathrm{SO}_{4}{ }^{2-}$ are well correlated with $\mathrm{Cl}^{-}$concentration for both sampling period in August and November 2007 ( $r=0.776$, and $r=0.717$, respectively $)$

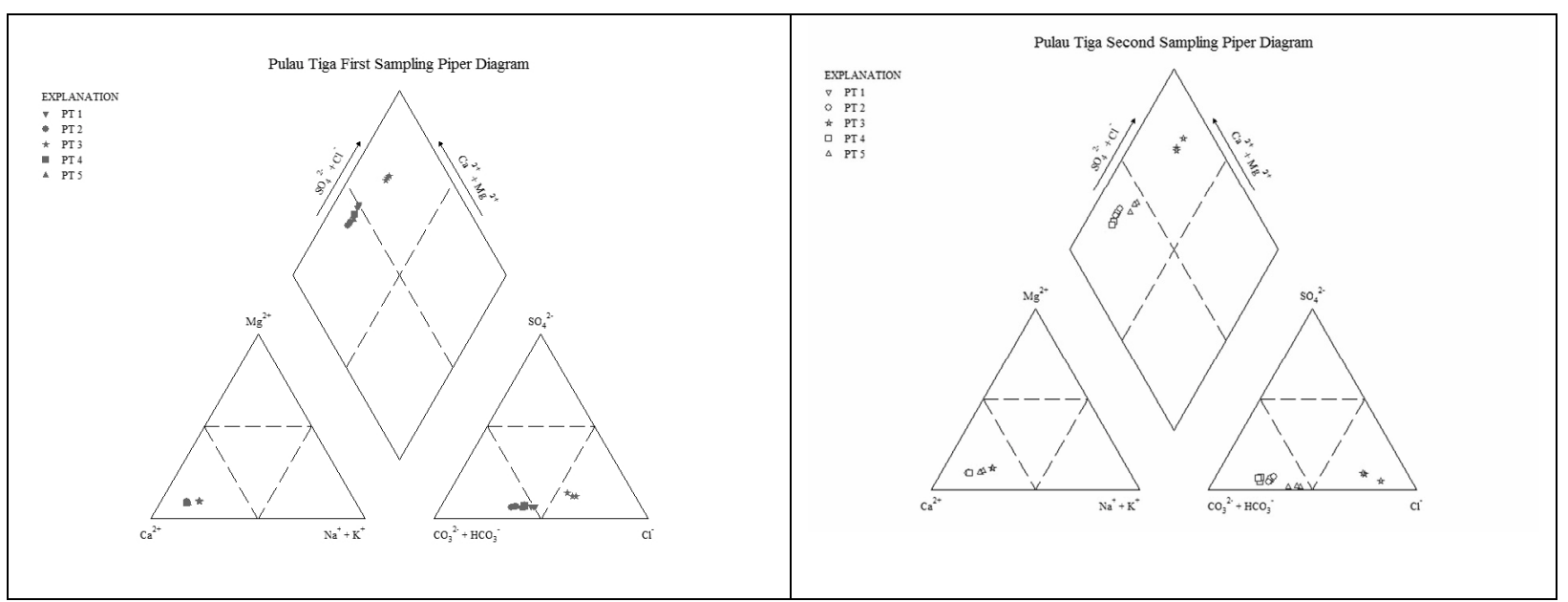

Figure 5. Piper Plot of groundwater samples collected during August 2007 (left) and November 2007 (right). 


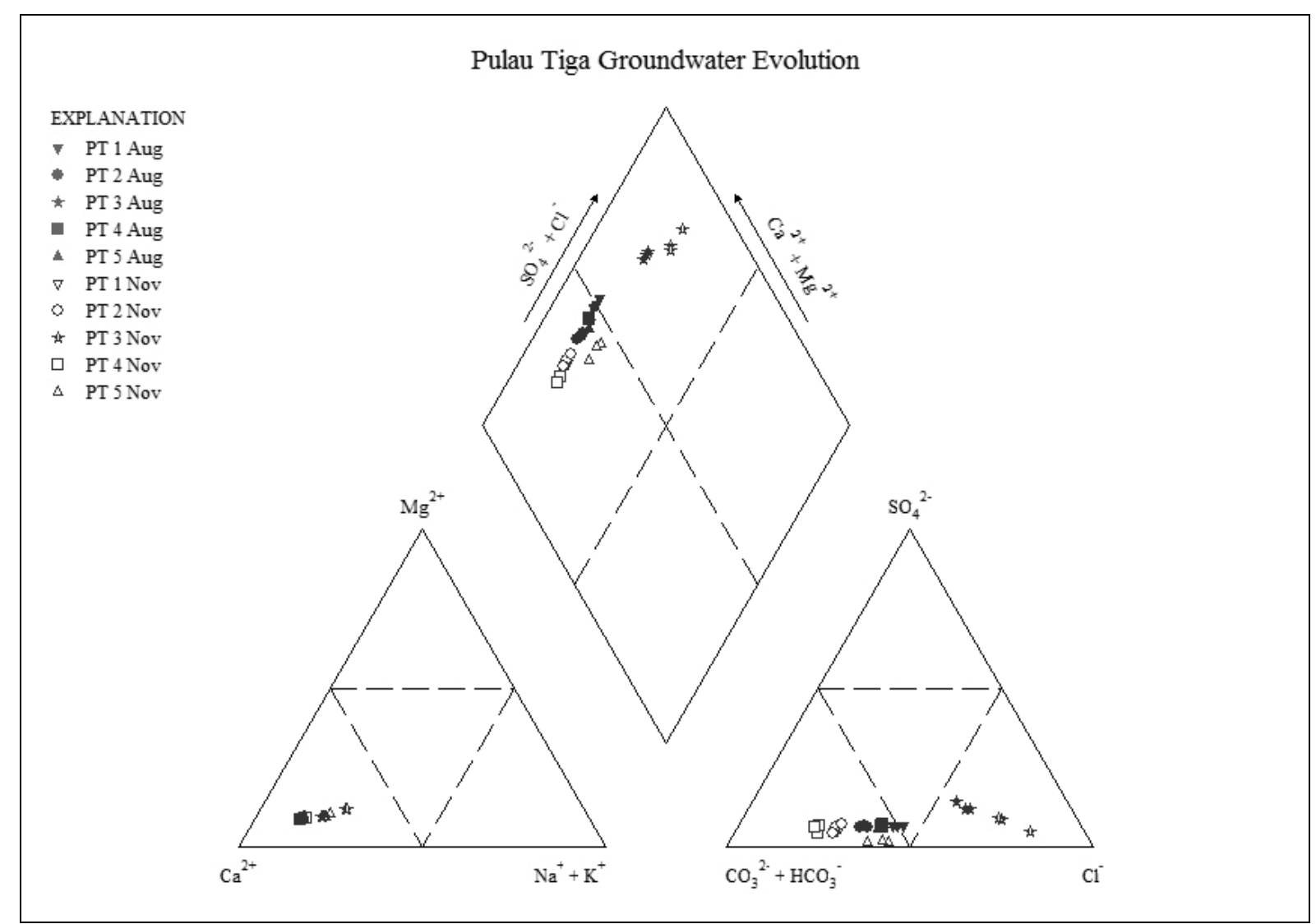

Figure 6. Piper diagram showing overall composition of groundwater samples collected during August and November 2007 